\title{
リウマチ様関節炎の関節液中の白血球遊走因子
}

\author{
神原 武*, 岡元 勉**
}

Chemotactic factor $(s)$ for leukocytes in the rheumatoid synovial fluids

Takeshi Kambara*, Tsutomu Okamoto**

われわれが追求してきたモルモットの遅延型アレルギ 一反応局所の 3 種のマクロファージ遊走因子 (MCFS-1, $2,3)$ の研究を拡大してヒトの慢性炎症性疾患に analogy を求めることと, リウマチ様関節炎 (RA) 組織には単 核球 (MNL) 浸潤が強く多核球 (PMN) 浸潤が汪とん どみられないのに，RA 関節液(RA-SF)には逆に PMN が多い点に興味をいだいたことから，RA の chemical mediation を知る第一歩として RA-SF 中の白血球遊走 因子について検討を加えてみた. Ward \& Zweifler ${ }^{1}$ が RA-SF 中の PMN 遊走因子は C5a であるといっ ているが，C5a は PMN のみならず MNL にも強い 遊走活性を示すので, RA-SF 中の PMN と MNL の 浸潤の差を説明するのは困難である.

\section{方 法}

30 例の RA-SF と対照として 30 例の OA-SF を採取 乙, 白血球数を数光, 遠沈上清を $-20 \sim 80^{\circ} \mathrm{C}$ に保存, 使 用した。 白血球遊走活性は agarose 法と Boyden 法に て測定した。健康人末梢血の bubby coat cells から Ficoll-Conray 法にて PMN 分画 (90\% 以上 PMN) と MNL 分画 (30\%が単球, $70 \%$ がリンパ球) を得, 洗浄 後 30 mM HEPES, pH 7.4 と 10\% FCS 加 RPMI 1640 に懸濁使用した.

\section{結 果}

(1) RA-SF 中には平均 $16,500 / \mathrm{mm}^{3}$ の白血球がみら れ, 約 $80 \%$ PMN, 20\%が MNL であり, OA-SF で は白血球数は $1,000 / \mathrm{mm}^{3}$ 以下であった。一方 RA の滑 膜組織には多数のリンパ球, プラスマ細胞, マクロファ ージがみられるが，PMN はきわめて少ない。

(2) RA-SF をモルモット皮内に注射すると白血球浸 潤を起こし, RA-SF 中に白血球遊走因子の存在するこ とを示唆した2). in vitro でも RA-SF には agarose 法 で強いPMN 遊走活性がみられ（図 1)，OA-SF では 弱い. Boyden 法でも同様であった. agarose 法での遊 走パターンはロケット型で, ZAS のそれと似て抢り, fMLP のそれとは異なる。 この遊走活性と RA-SF 中の 白血球数はよく相関し $(r=0.690, P<0.001)$ (図 2 ), RA-SF 中のこの遊走因子は PMN 遊走の natural me-

* Department of Allergy, Institute for Medical Immunology, Kumamoto University Medical School 熊本大学医学部付属免疫研究所

** Division of Orthopedic Surgery, Department of Surgery, Saga Medical School 佐賀医科大学 整形外科学教室

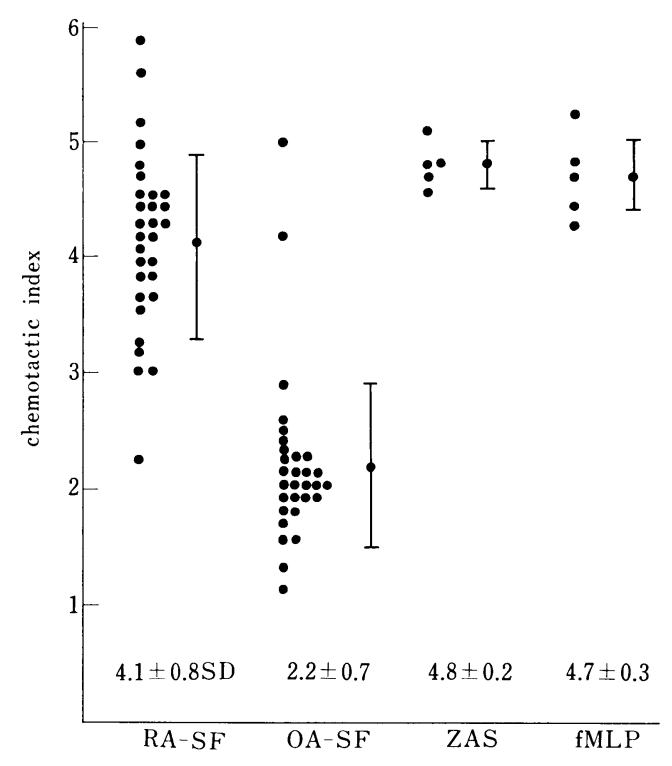

図 1 chemotactic activities for PMNs in RA- and OA-SF measured by agarose method

Chemotactic index was expressed as chemotaxis/ spontaneous migration. ZAS and fMLP $\left(10^{-7} \mathrm{M}\right)$ were used as positive controls.

diator と考えられる.

(3)この $\mathrm{PMN}$ 遊走因子の本態を知るために種々の 抗血清を用い，遊走活性の抑制をみた（表 1). RA-SF 中の PMN 遊走活性は抗ヒト血清抗体, 抗 C5 抗体, 抗 C5a 抗体で強く抑制され, 抗 IgG 抗体である程度 抑制された。 したがって, この主要遊走因子は C5 由来 因子で, たぶん C5a 様物質と考えられた。この遊走因 子の分子量を知るために, RA-SF をヒアルロニダーゼ 処理後セファデックス G-50 で溶出すると, 主要な遊走 活性は分子量14,000の部に溶出し C5a と考えられた。 別に分子量 30,000 以上の部にも遊走活性がみられた（図 3). しかし前者にはアナフィラトキシン活性（血管透 過活性）がみられなかった。 C5a にはつよいアナフィラ トキシン活性が存在することが知られている。一方われ われは, hippuryl-L-arginine を基質として RA-SF 中 に carboxypeptidase B 様酵素が存在することを見いだ した。これらのことから上記の 小分子遊走因子は C5a それ自体ではなく，C5a des Arg の可能性があること が示唆された。 また RA-SF 中の MNL 遊走活性は agarose 法でも Boyden 法でもみられなかった。 セファ デックス溶出分画にもみられないので, 遊走活性抑制物 質の効果とは考えがたく, 遊走因子そのものの問題と考 
表 1 effect of anti-sera on chemotactic activity for PMN in RA-SF*

\begin{tabular}{l|c|c}
\hline \multicolumn{1}{c|}{ samples } & $\begin{array}{c}\text { chemotactic index } \\
(\text { mean } \pm \text { SD) }\end{array}$ & $\%$ inhibition \\
\hline SF+ buffer** & $3.94 \pm 0.10$ & 2 \\
SF + normal rabbit & $4.01 \pm 0.16$ & 0 \\
$\quad$ serum & $1.17 \pm 0.05$ & 95 \\
SF+anti-HS*** & $3.76 \pm 0.21$ & 8 \\
SF+anti-C3 & $1.24 \pm 0.09$ & 92 \\
SF+anti-C5 & $1.21 \pm 0.12$ & 93 \\
SF + anti-C5a & $3.33 \pm 0.09$ & 22 \\
SF + anti-IgG &
\end{tabular}

* $10 \mu l$ of anti-sera was added to $50 \mu l$ of SF.

** phosphate-buffered saline ( $\mathrm{pH}$ 7.3)

*** antibody to whole human serum

表 2 chemotactic activity and anaphylatoxin activity of C5a and C5a des-Arg

\begin{tabular}{l|c|c|c}
\hline \multirow{2}{*}{ samples* } & \multicolumn{2}{|c|}{$\begin{array}{c}\text { chemotactic activity } \\
\text { (migrated cell/5HPF) } \\
\text { (mean } \pm \text { SD) }\end{array}$} & $\begin{array}{c}\text { anaphylatoxin } \\
\text { activity [dye } \\
\text { leakage( } \mu \mathrm{g})]\end{array}$ \\
\cline { 2 - 3 } & PMN & MNL & \\
\hline $\mathrm{C} 5 \mathrm{a}(15 \mu \mathrm{g} / \mathrm{m} l)$ & $710 \pm 35$ & $435 \pm 20$ & 25 \\
$\mathrm{C} 5 \mathrm{a}(5 \mu \mathrm{g} / \mathrm{m} l)$ & $394 \pm 11$ & $178 \pm 11$ & 16 \\
$\mathrm{C} 5 \mathrm{a} \mathrm{des-Arg}$ & $618 \pm 45$ & $12 \pm 4$ & 0 \\
$\begin{array}{l}(450 \mu \mathrm{g} / \mathrm{m} l) * * \\
\mathrm{C} 5 \mathrm{a} \mathrm{des}-\mathrm{Arg}\end{array}$ & $358 \pm 33$ & $3 \pm 1$ & 0 \\
$(45 \mu \mathrm{g} / \mathrm{ml})$ & $387 \pm 44$ & $5 \pm 1$ & ND \\
$\mathrm{RA}-\mathrm{SF}$ & $732 \pm 21$ & $422 \pm 19$ & ND \\
$\mathrm{fMLP}$ & & &
\end{tabular}

* Test samples were diluted with phosphatebuffered saline ( $\mathrm{pH}$ 7.3).

** C5a was digested by immobilized carboxypeptidase $\mathbf{B}$ for 10 minutes at room temperature.

えられた。

(4) そこで in iitro で C5a と C5a des Arg を作成 し， PMN および MNL 遊走活性とアナフィラトキシ ン活性を検討した（表 2). C5a は PMN にも MNL にも強い遊走活性を示し，モルモット皮膚にアナフィラ トキシン活性をもつ。一方, C5a des Arg は PMN 遊 走活性が低下して，9３0 倍の大量で C5a と同じ遊走 活性を示すが，依然として PMN 遊走活性を保持して いる. RA-SF 中の白血球遊走活性に相当する遊走活性 を示す C5a des Arg の量は $45 \mu \mathrm{g} / \mathrm{ml}$ であり, その 10 倍量の C5a des $\operatorname{Arg}(450 \mu \mathrm{g} / \mathrm{ml})$ でも MNL 遊走活性 はきわめて弱く, アナフィラトキシン活性はみられなか った。

\section{考 察}

RA-SF 中の白血球遊走因子は，抗 C5a 抗体で抑制

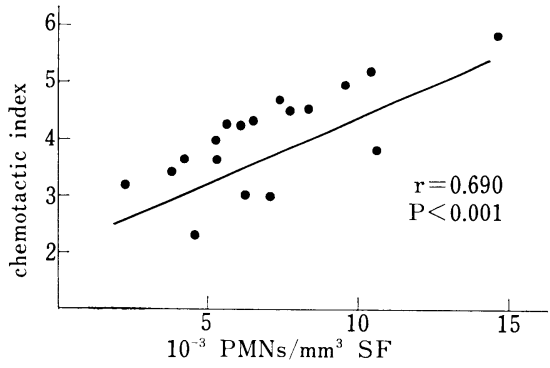

図 2 correlation between chemotactic activity for PNMs in RA-SF and number of PMNs in the SF

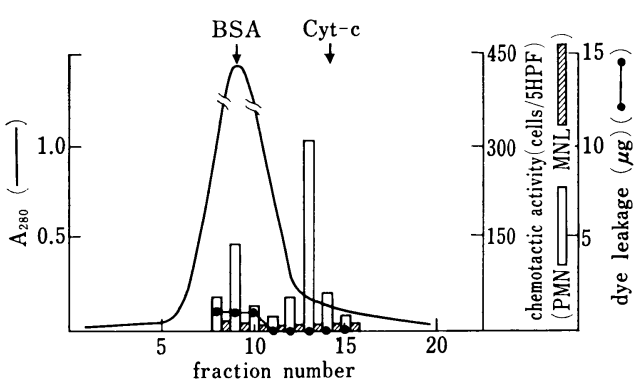

図 3 Sephadex G-50 elution profile of chemotactic activity for both PMNs and MNLs and of anaphylatoxin activity in RA-SF

Anaphylatoxin activity was expressed by extravascular dye leakage $(\mu \mathrm{g})$. The eluant was PBS, $\mathrm{pH}$ 7.3, and fractions were collected every 1.5 $\mathrm{m} l$. BSA and Cyt-c were chromatographied as molecular weight makers.

される分子量14,000のものでアナフィラトキシン活性を もたず，MNL 遊走活性もみられないので, 生化学的同 定はまだなされていないが，C5a そのものではなく C5a des Arg であろらと考兄れる。このことから RA-SF 中に PMN が多い理由も説明できる.

抗血清を恵贈くださった Dr. E.L. Becker (Univ. Connecticut）と津元博士（化血研）に深謝します.

\section{文 献}

1) Ward, P.A., Zweifler, N.J.: Complement-derived leukotactic factors in inflammatory synovial fluids of humans. J. Clin. Invest. 50: 606-616, 1971.

2) Kambara, T., Kutsuna, T., Okamoto, T., Nakamura, T.: Inflammatory activities of synovial fluids from rheumatoid and osteoarthritis to guinea pig skin. Acta Pathol. Jpn. 32: 575$583,1982$. 